\title{
REVIEW
}

\section{NEUROMUSCULAR TAPING APPLICATION OPPORTUNITIES IN NURSING: A LITERATURE REVIEW}

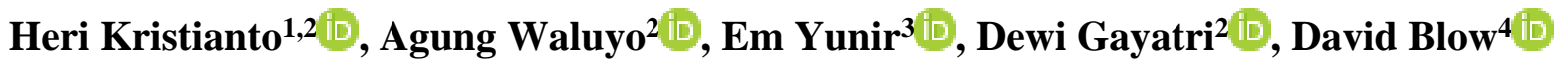 \\ ${ }^{l}$ Department of Medical Surgical Nursing, School of Nursing, Faculty of Medicine, Universitas Brawijaya, Malang, Indonesia \\ ${ }^{2}$ Faculty of Nursing, Universitas Indonesia, Depok, Indonesia \\ ${ }^{3}$ Department of Internal Medicine, Faculty of Medicine, Universitas Indonesia, Jakarta, Indonesia \\ ${ }^{4}$ NeuroMuscular Taping Institute, Roma, Italy
}

Received April 5, 2020; Accepted August 13, 2020. Copyright: This is an open access article under the CC BY-NC-ND license.

\begin{abstract}
Aim: This study aims to identify nursing problems that can be assisted or resolved with neuromuscular taping, and to identify the characteristics of neuromuscular taping interventions in the field of nursing. Design: A narrative literature review. Methods: A journal search was conducted using the keywords "neuromuscular taping" to collect relevant articles published within the last five years from databases. The inclusion criteria were: randomized controlled trials, quasi-experimental or case reports, participants aged over 17 years, full text articles, studies focusing on nursing problems, and written in English. Twelve journal articles were selected and analyzed using PICO, PEDro scale, ROBINS-I tool, and Pierson score, with a domain/class approach, and list of nursing diagnoses. Results: The results of the literature review indicated that most studies were conducted in Europe with adults and seniors as participants. There were eight randomized controlled trials reports with PEDro scores in a range of 8-9; one quasi-experimental study with ROBINS-I scale in a range of 2; and three case reports with Pierson scores in a range of 9-10 for two articles, and 6-8 for another. All articles provided results which could help with nursing problems. Conclusion: Neuromuscular taping can be applied for acute pain, chronic pain, impaired physical mobility, impaired walking, fatigue, and risk for unstable blood pressure.
\end{abstract}

Keywords: eccentric, fatigue, mobility, nursing, pain, neuromuscular taping, unstable blood pressure, walking.

\section{Introduction}

The application of neuromuscular taping (NMT) as a complementary therapy to help the rehabilitation of patients has developed rapidly in recent years. This therapeutic method is supported by several experimental studies and case studies with a focus on rehabilitation (Blow, 2012). The most problematic issue concerning discussions on taping research is in the definition of "taping" itself. Two types of taping are used therapeutically. The first is the use of a stretching tape, in a bandage or compression taping application, e.g., Kinesio Taping, functional taping, and others which use a specific compression or stretching application methodology (also known as a neuromuscular bandage).

The second involves a non-stretching tape, in a decompression taping application. NMT refers to a specific decompression taping application methodology. Several studies have shown that NMT

Corresponding author: Agung Waluyo, Department of Medical Surgical Nursing, Faculty of Nursing, Universitas Indonesia, Gedung Rumpun Ilmu Kesehatan E lt. 7 Jalan Prof. Dr. Sudjono D Pusponegoro, Kampus UI, Depok-16424, Indonesia, email: agungwss@ui.ac.id can help in the management of multiple sclerosis (Berlingeri et al., 2016), hemiplegia (Camerota et al., 2014), sports injuries (Aguilar et al., 2016; Lima et al., 2018; Russo et al., 2018), musculoskeletal disorders (Conejo et al., 2018), hypertension (Shah et al., 2018), cervical pain (Villota-Chicaíza \& Fernández-Niño, 2018), adhesive capsulitis (Sinaj et al., 2015), and hypermobility (Camerota et al., 2015). David Blow, developer of the basic concept of NMT, is very supportive of its development in the field of nursing. NMT could be applied in nursing management and developed within the scope of professional nursing practice, e.g., to reduce edema, to reduce pain, and for circulatory disorders. Therefore, an initial study of existing research associated with aspects of nursing is required. The development of NMT research in the field of nursing is very important for future applications.

The working principle of NMT is to provide eccentric stimulation to the skin over muscles, tendons, nerves, and lymphatic and blood vessels (Blow, 2018). NMT is different from other types of taping since the tape is not applied with tension, creating a stretching and consequent concentric action when it is applied, emphasizing traction and resulting in compression. 
NMT is stated to use an eccentric application technique (tape applied without tension or stretch), creating a mechanism of sensorimotor and proprioceptive modification (Chang et al., 2015; Lim \& Tay, 2015; Renner, 2012; Taheri et al., 2017). Our review of NMT publications indicates that applications of eccentric taping in the field of nursing have never been investigated. Based on the researchers' experience in nursing practice over two years (2017-2018), NMT can help alleviate a series of patient symptoms that cause problems for nurses, such as acute/chronic pain, impaired skin integrity, impaired tissue integrity, ineffective peripheral tissue perfusion, risk of peripheral neurovascular dysfunction, disturbed body image, impaired verbal communication, impaired physical mobility, impaired sitting, and impaired standing, with reference to standard nursing diagnoses (Herdman \& Kamitsuru, 2018). A case study on nursing care of patients with lupus suggests NMT can reduce pain, while another study suggests it can also improve the healing process in diabetic wounds (Kristianto, 2018; Kristianto et al., 2017). It has been personally and professionally interesting to investigate these results, which can help patients in the management of acute and chronic conditions, and provide new opportunities in nursing care management. NMT can support the development of rehabilitation nurse competencies, assisting the design and implementation of treatment strategies to improve overall health (Camicia et al., 2014). In light of such observations, a literature review related to the application of NMT to problems in nursing practice seems timely.

\section{Aim}

The purpose of the literature review was to identify nursing problems that can be assisted or resolved by NMT, to identify the characteristics of NMT interventions in each case, and to analyze the opportunities for NMT application in the field of nursing.

\section{Methods}

\section{Eligibility criteria}

The journal search included articles published in the five-year period between 2013 to 2018. The literature review focused on quantitative studies of adult patients ( $\geq 17$ years), full-text available, with focus on nursing problems. Only articles written in English were considered for analysis.

\section{Search Strategy}

The latest articles on the development of neuromuscular taping were obtained from the databases of PubMed, Clinical Key, EBSCO, ProQuest, Sage Pub, Google Scholar, and Willey Online. The keywords used in the search were "neuromuscular taping" to distinguish taping applications from other methods. The search obtained 14 titles from PubMed, seven titles from Clinical Keys, four titles from EBSCO, 16 titles from ProQuest, four titles from Sage Pub, 40 titles from Google Scholar, and five titles from Wiley Online. A total of 90 articles were found. Data were recorded in EndNote X8 (Bramer \& Bain, 2017).

\section{Study selection inc. PRISMA flow diagram}

An analysis of duplicate articles in databases was conducted using the EndNote X8 program. The selection criteria for the articles were based on the PICO approach ( $\mathrm{P}$ - patient responses were emphasized in the study; I - interventions were made using a neuromuscular taping method; $\mathrm{C}$ - the comparison group used placebo, standard treatment, or measurements of pretest/posttest; $\mathrm{O}$ - the expected outcome related to nursing problems), with PRISMA flow diagram (Figure 1) (Dhammi \& Haq, 2018; Frampton et al., 2017). Seven of the 22 selected articles were excluded, as the full text was not found in the search process. Three articles were removed from the 15 full text articles because the results of NMT use did not relate to nursing aspects, NMT application was unclear, or the concept overlapped with other taping methods.

\section{Evaluation of quality of articles}

For quality assessment, the articles were divided into three groups, namely the random clinical trial (RCT) group, the quasi-experimental group, and the case report group. Research using a RCT design was analyzed using the PEDro Scale instrument in a range of $0-10$ with 11 items: 1 ) inclusion criteria and source; 2) random allocation; 3) allocation concealment; 4) baseline comparability; 5) blinding of subjects; 6) blinding of therapists; 7) blinding of assessors; 8) over $85 \%$ follow-up; 9) intention-to-treat analysis; 10) between-group comparison; and 11) point estimates and variability (Tie Parma et al., 2017). Item 1 is not used in calculating PEDro scores as it relates to external validity. The case report studies were analyzed using the Pierson method in a range of 0-10 (Implications of total score: 9-10 = the report is likely to be a worthwhile contribution to the literature; $6-8=$ the reader should be cautious about the validity and clinical value of the report; 5 or less $=$ the report is of insufficient quality for publication) (Gopikrishna, 2010). Pierson's method assesses the aspects of documentation, uniqueness, educational value, objectivity, and interpretation. Research using quasiexperiment was analyzed using the "Risk of Bias In 


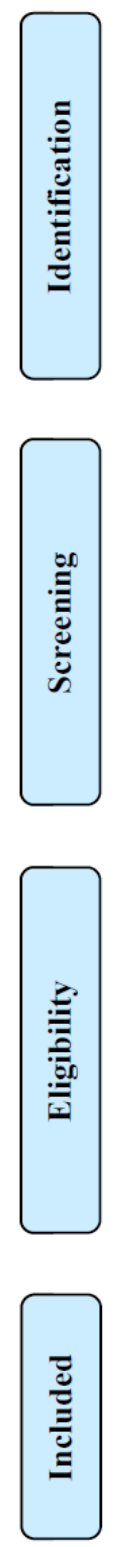

Records identified through database searching: PubMed $(\mathrm{n}=14)$, Clinical Keys $(n=7), \operatorname{EBSCO}(n=4)$, ProQuest $(n=16)$,

Sage Pub $(n=4)$, Willey online $(n=5)$ $\Sigma \mathrm{n}=50$
Additional records identified through other sources: Google scholar

$$
(\mathrm{n}=40)
$$

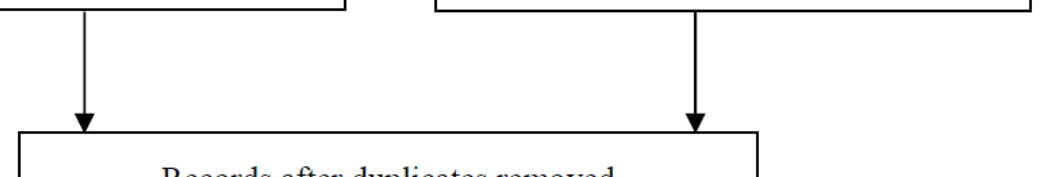

$$
(n=34)
$$

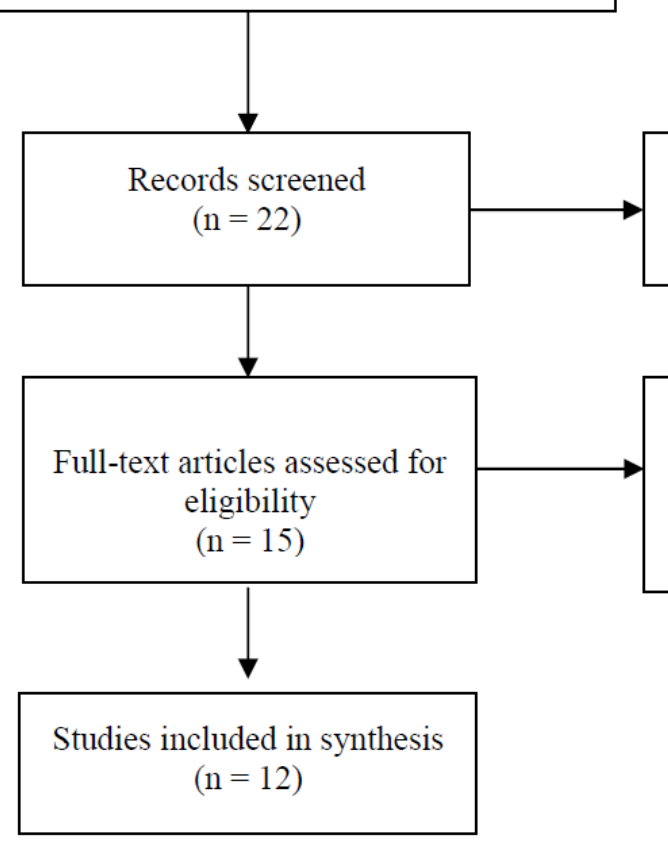

Full-text articles excluded, with reasons

$$
(\mathrm{n}=3)
$$

Figure 1 PRISMA Flow diagram

Non-Randomised Studies of Interventions" (ROBINS-I) tool that focuses on evaluating internal validity through the measurement of seven specific domains: confounding, selection of participants into study, classification of interventions, deviation from intended interventions, missing data, measurement of outcomes, and selection of reported results (Thomson et al., 2018).

\section{Data Extraction}

The search returned 12 main articles, which became the focus of the analysis. There were eight research articles with an RCT research design, one research article with a quasi-experimental design, and three research articles with case reports, in the period 2013-2018. The mapping process was carried out based on domain, class, and nursing diagnosis (Herdman \& Kamitsuru, 2018).

\section{Results}

NMT research was mostly conducted in Italy, Spain, Brazil, Albania, Colombia, and the UK. In the RCT group, the age characteristics in the activity/rest/exercise domain/class ranged from 23-75 years, in a sample of 216 people (control group: 118 participants; experimental group: 98 participants). Age characteristics in the physical/comfort domain/class ranged from 17-82 years, in a total sample of 147 people (control group: 71 participants; experimental group: 76 participants), distinguished by acute and chronic conditions. Age characteristics in the activity/rest/energy balance domain/class ranged from 50-82 years, in a sample size of 40 people (control group: 20 participants; experimental group: 20 participants). In the quasi-experimental study, 
the age characteristics in the activity/rest/exercise and comfort/physical comfort domains/classes ranged from 38-52 years, in a sample of 60 people (control group: 15 participants; experimental group: 45 participants). In the case report group, the age of patients in the activity/rest/exercise domain/class ranged from 17 to 37 years, and the age of patients in the activity/rest/cardiovascular domains/classes was 57.3 years, in a total of nine cases (two men and seven women).

The literature review of the articles is presented in tables 1-3. The PEDro score in the RCT research group was in a range of 8-9, indicating that the effectiveness of the use of NMT for overcoming problems related to mobilization disorders, acute pain, chronic pain, fatigue, and disturbances is in the upper range (0-10). ROBINS-I scale in the quasi- experimental research group was in a range of 2 (moderate risk of bias), indicating that the study is sound for a non-randomized study with regard to this domain, although it cannot be considered comparable to a well-performed randomized trial (Sterne et al., 2016). Analysis of two case report articles shows that in the range of 9-10, the report will provide a valuable contribution to the development of NMT, especially in helping overcome the problem of impaired physical mobility. However, one report was in the range of 6-8, meaning that we must be careful in assessing the validity and the clinical significance of the application of NMT to alleviating the problem of risk for unstable blood pressure.

Table 1 Evaluation of articles using the PEDro Score

\begin{tabular}{|c|c|c|c|c|c|c|}
\hline \multirow{2}{*}{$\begin{array}{l}\text { Randomized } \\
\text { controlled trials } \\
\text { author (year) }\end{array}$} & \multirow{2}{*}{$\begin{array}{l}\text { PEDro } \\
\text { score }\end{array}$} & \multicolumn{3}{|c|}{ NANDA International (2018-2020) } & \multirow{2}{*}{$\begin{array}{c}\text { Taping application } \\
\text { (location/time) }\end{array}$} & \multirow{2}{*}{$\begin{array}{c}\text { Other } \\
\text { treatments }\end{array}$} \\
\hline & & domain & class & $\begin{array}{c}\text { nursing } \\
\text { diagnosis }\end{array}$ & & \\
\hline \multirow[t]{2}{*}{ Sinaj et al. (2015) } & 9 & activity/rest & $\begin{array}{l}\text { activity/ } \\
\text { exercise }\end{array}$ & $\begin{array}{l}\text { impaired } \\
\text { physical } \\
\text { mobility }\end{array}$ & $\begin{array}{l}\text { double fan shape } \\
\text { (shoulder/4 weeks) }\end{array}$ & $\begin{array}{l}\text { stretching } \\
\text { exercises } \\
\text { program }\end{array}$ \\
\hline & & comfort & $\begin{array}{l}\text { physical } \\
\text { comfort }\end{array}$ & acute pain & & \\
\hline $\begin{array}{l}\text { Aguilar et al. } \\
(2016)\end{array}$ & 9 & activity/rest & $\begin{array}{l}\text { activity/ } \\
\text { exercise }\end{array}$ & $\begin{array}{l}\text { impaired } \\
\text { physical } \\
\text { mobility }\end{array}$ & $\begin{array}{c}\text { "I " shape (foot/45 } \\
\text { minutes) }\end{array}$ & $\begin{array}{l}\text { completing } 45 \\
\text { min of running } \\
\text { (mean speed of } \\
12 \mathrm{~km} / \mathrm{h} \text { ) }\end{array}$ \\
\hline $\begin{array}{l}\text { Costantino et al. } \\
(2016)\end{array}$ & 9 & activity/rest & $\begin{array}{l}\text { activity/ } \\
\text { exercise }\end{array}$ & $\begin{array}{l}\text { impaired } \\
\text { walking }\end{array}$ & $\begin{array}{c}\text { fan shape } \\
\text { (quadriceps/2 } \\
\text { months) }\end{array}$ & - \\
\hline \multirow[t]{2}{*}{$\begin{array}{l}\text { Pillastrini et al. } \\
\text { (2016) }\end{array}$} & 9 & activity/rest & $\begin{array}{l}\text { activity/ } \\
\text { exercise }\end{array}$ & $\begin{array}{l}\text { impaired } \\
\text { physical } \\
\text { mobility }\end{array}$ & $\begin{array}{l}\text { "W" shape } \\
\text { (pectoralis major), } \\
\text { "Y" shape (deltoids }\end{array}$ & $\begin{array}{c}\text { standard } \\
\text { physical therapy } \\
\text { programs }\end{array}$ \\
\hline & & comfort & $\begin{array}{l}\text { physical } \\
\text { comfort }\end{array}$ & chronic pain & $\begin{array}{l}1 \text { month) } \\
\text { and supraspinatus/ }\end{array}$ & \\
\hline \multirow[t]{2}{*}{$\begin{array}{l}\text { Berlingeri et al. } \\
(2016)\end{array}$} & 9 & activity/rest & $\begin{array}{l}\text { activity/ } \\
\text { exercise }\end{array}$ & $\begin{array}{l}\text { impaired } \\
\text { physical } \\
\text { mobility }\end{array}$ & $\begin{array}{c}\text { "Y" shape (lumbar } \\
\text { paravertebral } \\
\text { muscles and } \\
\text { hamstring }\end{array}$ & $\begin{array}{l}\text { standard } \\
\text { physical } \\
\text { rehabilitation }\end{array}$ \\
\hline & & comfort & $\begin{array}{l}\text { physical } \\
\text { comfort }\end{array}$ & chronic pain & bilateral/1 week) & \\
\hline Lima et al. (2018) & 9 & comfort & $\begin{array}{l}\text { physical } \\
\text { comfort }\end{array}$ & acute pain & $\begin{array}{l}\text { "Y " and " I "shape } \\
\text { (deltoid) }\end{array}$ & - \\
\hline $\begin{array}{l}\text { Conejo et al. } \\
(2018)\end{array}$ & 8 & activity/rest & $\begin{array}{l}\text { physical } \\
\text { comfort } \\
\text { energy } \\
\text { balance }\end{array}$ & $\begin{array}{l}\text { chronic pain } \\
\text { fatigue }\end{array}$ & $\begin{array}{l}\text { “X "shape (carpal), } \\
\text { "I "shape (lumbar), } \\
\text { "I" and "Y "shape } \\
\text { (cervical/5 weeks) }\end{array}$ & $\begin{array}{l}\text { endocrine } \\
\text { therapy }\end{array}$ \\
\hline $\begin{array}{l}\text { Russo et al. } \\
(2018)\end{array}$ & 8 & activity/rest & $\begin{array}{l}\text { activity/ } \\
\text { exercise }\end{array}$ & $\begin{array}{l}\text { impaired } \\
\text { physical } \\
\text { mobility }\end{array}$ & $\begin{array}{c}\text { "I" shape } \\
\text { (ankle/1 week) }\end{array}$ & $\begin{array}{l}\text { proprioceptive } \\
\text { exercises on } \\
\text { unstable } \\
\text { surfaces } \\
\end{array}$ \\
\hline
\end{tabular}


Table 2 Evaluation of articles using the Pierson Score

\begin{tabular}{|c|c|c|c|c|c|c|}
\hline \multirow{2}{*}{$\begin{array}{l}\text { Case Report } \\
\text { author (year) }\end{array}$} & \multirow{2}{*}{$\begin{array}{l}\text { Pierson } \\
\text { Score }\end{array}$} & \multicolumn{3}{|c|}{ NANDA International (2018-2020) } & \multirow{2}{*}{$\begin{array}{c}\text { Taping } \\
\text { application } \\
\text { (location/time) }\end{array}$} & \multirow{2}{*}{$\begin{array}{c}\text { Other } \\
\text { treatments }\end{array}$} \\
\hline & & domain & class & $\begin{array}{c}\text { nursing } \\
\text { diagnosis }\end{array}$ & & \\
\hline $\begin{array}{l}\text { Camerota et } \\
\text { al. (2014) }\end{array}$ & 9 & activity/rest & activity/exercise & $\begin{array}{l}\text { impaired } \\
\text { physical } \\
\text { mobility }\end{array}$ & $\begin{array}{c}\text { fan shape } \\
\text { (shoulder), } \\
\text { "I "shape (hand/2 } \\
\text { weeks) }\end{array}$ & physical therapy \\
\hline $\begin{array}{l}\text { Camerota et } \\
\text { al. }(2015)\end{array}$ & 9 & activity/rest & activity/exercise & $\begin{array}{l}\text { impaired } \\
\text { physical } \\
\text { mobility }\end{array}$ & $\begin{array}{c}\text { “I “shape (low } \\
\text { back spine), “Y } \\
\text { “shape (knee/2 } \\
\text { weeks) }\end{array}$ & - \\
\hline $\begin{array}{l}\text { Shah et al. } \\
(2018)\end{array}$ & 7 & activity/rest & $\begin{array}{l}\text { cardiovascular/ } \\
\text { pulmonary } \\
\text { responses }\end{array}$ & $\begin{array}{c}\text { risk for } \\
\text { unstable blood } \\
\text { pressure }\end{array}$ & $\begin{array}{c}\text { "I "shape } \\
\text { (between } 1^{\text {st }} \\
\text { cervical and } 2^{\text {nd }} \\
\text { thoracic/1 weeks) }\end{array}$ & $\begin{array}{c}\text { two of the } \\
\text { patients had } \\
\text { been taking } \\
\text { antihypertensive } \\
\text { medication and } \\
\text { were asked not } \\
\text { to change this } \\
\text { during this } \\
\text { study }\end{array}$ \\
\hline
\end{tabular}

Table 3 Evaluation of Articles Using the ROBINS-I

\begin{tabular}{|c|c|c|c|c|c|c|}
\hline \multirow{2}{*}{$\begin{array}{l}\text { Quasi- } \\
\text { experimental } \\
\text { author (year) }\end{array}$} & \multirow{2}{*}{$\begin{array}{l}\text { ROBINS-I } \\
\text { Scale }\end{array}$} & \multicolumn{3}{|c|}{ NANDA International (2018-2020) } & \multirow{2}{*}{$\begin{array}{c}\text { Taping } \\
\text { application } \\
\text { (location/time) }\end{array}$} & \multirow{2}{*}{$\begin{array}{c}\text { Other } \\
\text { treatments }\end{array}$} \\
\hline & & domain & class & $\begin{array}{c}\text { nursing } \\
\text { diagnosis }\end{array}$ & & \\
\hline \multirow{3}{*}{$\begin{array}{l}\text { Villota-Chicaíza } \\
\text { \& Fernández- } \\
\text { Niño (2018) }\end{array}$} & 2 & activity/rest & activity/exercise & impaired & "Y" and "I" shape & physiotherapy \\
\hline & & & & $\begin{array}{l}\text { physical } \\
\text { mobility }\end{array}$ & (cervical/5 days) & \\
\hline & & comfort & $\begin{array}{l}\text { physical } \\
\text { comfort }\end{array}$ & acute pain & & \\
\hline
\end{tabular}

\section{Discussion}

NMT research has mostly been conducted in Europe. Further research should be conducted in other countries so that it can produce more varied research reports, including variable patient characteristics and tape applications. The different geographical and climatic conditions in each country may affect the resistance of the tape attached to the skin. In the research, patients who experienced impaired mobility were adults, whereas the elderly are at higher risk of impaired mobility, which is exacerbated by chronic diseases such as Chronic Obstructive Pulmonary Diseases and the subsequent effects of fatigue and pain may increase the risk of injury and falls (MedinaMirapeix et al., 2018; Törnvall et al., 2016; Yeom et al., 2015). Further research is also required to support the case study indicating that NMT can reduce blood pressure, which could have beneficial indications for a series of conditions, including improved mobility (Shah et al., 2018). According to the analysis, NMT applications may provide benefits in the management of the activity/rest domain (activity/exercise, energy balance, and cardiovascular/pulmonary responses), and the comfort domain (physical comfort). Nursing diagnoses include acute pain, chronic pain, impaired physical mobility, impaired walking, fatigue, and risk for unstable blood pressure. Impaired physical mobility is the predominant nursing diagnosis that can be alleviated by NMT.

Impaired physical mobility refers to the limitation of purposeful movement of the body or one or more extremities (Herdman \& Kamitsuru, 2018). Cases related to NMT in this article include foot problems of athletes, multiple sclerosis, cerebral palsy hemiplegia and post-stroke upper limbs, and Joint Hypermobility Syndrome of the lower extremities. Case reports on multiple sclerosis indicated that NMT was able to affect the modulation of micro Ribonucleic Acids (miRNAs) during the rehabilitation phase (Vallelunga et al., 2017). The risk of impaired mobility also increases Type 2 Diabetes Mellitus (DM) patients in the elderly (6\%/year), peripheral neuropathy (40\%), history of stroke (123\%), insulin therapy (117\%), and arthritis (82\%), which will affect Activities of Daily Living (ADL) (Bianchi et al., 2013; Bruce et al., 2005). The types of taping used to overcome mobility disorders were I, Fan, Y and W (Aguilar et al., 2016; Camerota et al., 2014, 2015; Costantino et al., 2016; Pillastrini et al., 2016). Studies regarding different 
types of tape are limited; although the standard type of tape for each anatomical position has been determined by David Blow (Blow, 2012, 2018). The application of elastic tape has been shown to modify sensorimotor stimulation, affecting peripheral conditions (Santos et al., 2017). Further research into cases of specific mobility disorders is required.

Acute pain is an unpleasant sensory and emotional experience associated with actual or potential tissue damage and (as described by the International Association for the Study of Pain) a sudden or slow onset of any intensity from mild to severe, with an anticipated or predictable end, and with a duration of less than three months (Herdman \& Kamitsuru, 2018). One article focuses on pain in the deltoid muscle in hand ball athletes as one of the components of physical injury. Further research is required focusing on NMT's influence on biological and chemical injury agents, e.g., burns and postoperative conditions. $\mathrm{P}$ substance in serum is closely associated with the occurrence of acute pain (Blow, 2018; Lisowska et al., 2016), and further research is required on whether NMT can influence $\mathrm{P}$ substance. The development of NMT in the management of acute pain in cancer and postoperative care also requires further research, e.g., in terms of surgical wound care. This is consistent with the recommendation for nurses to develop pain interventions in relation to the provision of treatment therapy for cancer (Sundaramurthi et al., 2017). The forms of tape used in handling acute pain were Y and I (Lima et al., 2018).

Chronic pain is an unpleasant sensory and emotional experience associated with actual or potential tissue damage and (as described by the International Association for the Study of Pain) sudden or slow onset of any intensity, from mild to severe, constant or recurring without anticipated or predictable end, and with a duration of more than three months (Herdman \& Kamitsuru, 2018). The cases discussed in this article focus on pain related to breast cancer. Further research might focus on chronic pain in cases of chronic musculoskeletal conditions, contusion, crush injury, damage to nervous system, fracture, genetic disorders, imbalance of neurotransmitters, neuromodulators and receptors, immune disorders, impaired metabolic functioning, ischemic conditions, muscle injury, posttraumatic related conditions, prolonged increase in cortisol levels, and spinal cord injury (Herdman \& Kamitsuru, 2018). Pain is closely related to cognitive status, and NMT management of pain needs to address this aspect in the development of a treatment modality for nursing. Chronic pain in neuropathic conditions associated with Type $2 \mathrm{DM}$ can contribute to depression, which has a negative impact on quality of life (de Lima et al., 2019). The NMT application method for Type $2 \mathrm{DM}$ requires further exploration. The forms of tape used in the research related to chronic pain were W, Y, X and I (Conejo et al., 2018; Pillastrini et al., 2016).

Impaired walking is a limitation of independent movement relating mostly to the lower limb and foot (Herdman \& Kamitsuru, 2018). Cases in which impaired walking is treated with NMT include multiple sclerosis. According to nursing studies, NMT might be applied in cases of alteration and impaired balance, musculoskeletal impairment, and neuromuscular impairment (Herdman \& Kamitsuru, 2018). The effects of NMT on impaired walking should be analyzed in terms of leg strength, endurance of trunk, knee flexion, range of motion, limb velocity, and physical performance measures (Ward et al., 2016). They can have an impact on patients' ability to perform ADL. The form of tape used in treating impaired walking was fan (Costantino et al., 2016).

Fatigue is an overwhelming sustained sense of exhaustion and decreased capacity for physical and mental activity/work (Herdman \& Kamitsuru, 2018); with the case discussed in this article relating to breast cancer. NMT may be applied in cases of pregnancy and discomfort due to certain conditions (Herdman \& Kamitsuru, 2018). The results of the study show that fatigue interventions consist of pharmacological and complementary medicine, psychological/behavioral treatments, and exercise (Hulme et al., 2018). NMT may be used in fatigue management to improve general energy and activity. Again, further research is required. The forms of tape used were $\mathrm{W}, \mathrm{Y}, \mathrm{X}$ and I (Conejo et al., 2018).

Those at risk for unstable blood pressure are susceptible to fluctuating forces of blood flowing through arterial vessels which may compromise health (Herdman \& Kamitsuru, 2018). The case discussed in this article is systemic arterial hypertension. According to nursing studies, NMT can be applied in circulatory disorders. In DM patients, impaired peripheral perfusion can cause limitations in walking. The results of the study show that measurement of circulatory foot status in DM should be accompanied by walking ability tests (Henni et al., 2018). NMT resulting in improvement in walking coordination may contribute to improving blood circulation of the foot in DM. Case studies of diabetic foot ulcer show that NMT can control the effects of the inflammatory response on wound base temperature and decrease erythema, due to improved peripheral circulation (Kristianto et al., 2019). The form of tape used in the case of systemic arterial hypertension was I (Shah et al., 2018). 
Thus, NMT appears to improve activity, reduce pain, improve circulation status, and reduce fatigue. This has implications for the development of nursing actions: e.g., nursing rehabilitation, pain management, wound care, orthopedic care, post-surgical care, vascular management, and hematoma. Conservation efforts include conservation of energy, structural integrity, personal integrity, and social integrity, to improve the quality of life of patients. According to the Levine model, the conservation model can be applied to areas of cardiology, obstetrics, gerontology, acute care (neurology), pediatrics, long-term care, emergency care, primary care, neonatology, critical care, and in the homeless community (Alligood \& Tomey, 2017). The application of NMT is very likely to develop a conservation-based intervention model that supports patient care management. Further experimental research in the area of nursing practice is required. Only publications in English, available from the electronic bibliographic database for the five years covered by the study were used.

\section{Conclusion}

NMT can be used for acute pain, chronic pain, impaired physical mobility, impaired walking, fatigue, and risk for unstable blood pressure. The literature review indicates that the eccentric application of NMT can be an effective tool in the field of nursing, and that further studies should be conducted.

\section{Ethical aspects and conflict of interest}

We declare that the literature review has no conflicts of interest or ethical issues.

\section{Acknowledgements}

We would like to thank the Library of Universitas Indonesia for their support in improving the composition of the search terms and procedural aspects of the search strategy. We would also like to acknowledge Professor Yati Afiyanti (Senior Lecturer in Faculty of Nursing, Universitas Indonesia) for her advice regarding the quality appraisal in nursing. The research was supported by funding from Universitas Indonesia, Hibah Tugas Akhir Mahasiswa Doktor (No: NKB-0096/UN2.R3.1/HKP05.00/2019)

\section{Author contributions}

Conceptualized this literature review (HK, AW, EY, DG, DB). Designed the article (HK, AW, EY, DG, DB). Defined the concepts and search items (HK, AW). The manuscript was written by HK with contributions from all authors.

\section{References}

Aguilar, M. B., Abián-Vicén, J., Halstead, J., \& GijonNogueron, G. (2016). Effectiveness of neuromuscular taping on pronated foot posture and walking plantar pressures in amateur runners. Journal of Science and Medicine in Sport, 19(4), P348-353. https://doi.org/10.1016/j.jsams.2015.04.004

Alligood, M. R., \& Tomey, A. (2017). Nursing theory and their work (8th ed.). St. Louis, Missouri: Elsevier Mosby, a.s.

Berlingeri, C., Camerota, F., Celletti, C., Turolla, A., Peraro, A., Blow, D., \& Sale, P. (2016). Possible applications of Neuromuscular Taping in pain reduction in Multiple Sclerosis subject: a preliminary report. Senses and Sciences, 3(4), 303-307.

Bianchi, L., Zuliani, G., \& Volpato, S. (2013). Physical disability in the elderly with diabetes: Epidemiology and mechanisms. Current Diabetes Reports, 13(6), 824-830. https://doi.org/10.1007/s11892-013-0424-6

Blow, D. (2012). Neuromuscular taping: from theory to practice (Digital ed.). Milan: Edi.ermes, a.s.

Blow, D. (2018). Neuromuscular taping: treatment of edemas, hematomas and scars. Milan: Edi.Ermes, a.s.

Bramer, W., \& Bain, P. (2017). Updating search strategies for systematic reviews using EndNote. Journal of the Medical Library Association, 105(3), 285-289.

https://doi.org/10.5195/jmla.2017.183

Bruce, D. G., Davis, W. A., \& Davis, T. M. E. (2005). Longitudinal predictors of reduced mobility and physical disability in patients with type 2 diabetes: the fremantle diabetes study. Diabetes Care, 28(10), 2441-2447. https://doi.org/10.2337/diacare.28.10.2441

Camerota, F., Galli, M., Cimolin, V., Celletti, C., Ancillao, A., Blow, D., \& Albertini, G. (2014). Neuromuscular taping for the upper limb in cerebral palsy: a case study in a patient with hemiplegia. Developmental Neurorehabilitation, 17(6), 384387. https://doi.org/10.3109/17518423.2013.830152

Camerota, F., Galli, M., Cimolin, V., Celletti, C., Ancillao, A., Blow, D., \& Albertini, G. (2015). The effects of neuromuscular taping on gait walking strategy in a patient with joint hypermobility syndrome/Ehlers-Danlos syndrome hypermobility type. Therapeutic Advances in Musculoskeletal Disease, 7(1), 3-10.

https://doi.org/10.1177/1759720X14564561

Camicia, M., Black, T., Farrell, J., Waites, K., Wirt, S., Lutz, B., \& Association of Rehabilitation Nurses Task Force (2014). The essential role of the rehabilitation nurse in facilitating care transitions: a white paper by the Association of Rehabilitation Nurses. Rehabilitation Nursing, 39(1), 315. https://doi.org/10.1002/rnj.135

Chang, W. D., Chen, F. C., Lee, C. L., Lin, H. Y., \& Lai, P. T. (2015). Effects of kinesio taping versus mcconnell taping for patellofemoral pain syndrome: a systematic review and metaanalysis. Evidence-Based Complementary and Alternative Medicine, 2015, ID 471208, 11. https://doi.org/10.1155/2015/471208

Conejo, I., Pajares, B., Alba, E., \& Cuesta-Vargas, A. I. (2018). Effect of neuromuscular taping on musculoskeletal disorders secondary to the use of aromatase inhibitors in breast cancer survivors: a pragmatic randomised clinical trial. 
BMC Complementary and Alternative Medicine, 18, 180. https://doi.org/10.1186/s12906-018-2236-3

Costantino, C., Pedrini, M. F., \& Licari, O. (2016). Neuromuscular taping versus sham therapy on muscular strength and motor performance in multiple sclerosis patients. Disability and rehabilitation, 38(3), 277-281. https://doi.org/10.3109/09638288.2015.1038365

de Lima, L. R., Stival, M. M., Funghetto, S. S., Volpe, C. R. G., Rehem, T. C. M. S. B., Santos, W. S., \& Funez, M. I. (2019). Lower quality of life, lower limb pain with neuropathic characteristics, female sex, and ineffective metabolic control are predictors of depressive symptoms in patients with type 2 diabetes mellitus treated in primary care. International Journal of Diabetes in Developing Countries, 39, 463-470. https://doi.org/10.1007/s13410-018-0667-5

Dhammi, I. K., \& Haq, R. U. (2018). How to write systematic review or meta-analysis. Indian Journal of Orthopaedics, 52(6), 575-577.

Frampton, G. K., Livoreil, B., \& Petrokofsky, G. (2017). Eligibility screening in evidence synthesis of environmental management topics. Environmental Evidence, 6(1), 27. https://doi.org/10.1186/s13750-017-0102-2

Gopikrishna, V. (2010). A report on case reports. Journal of Conservative Dentistry, 13(4), 265-271.

https://doi.org/10.4103/0972-0707.73375

Henni, S., Ammi, M., Gourdier, A.-S., Besnier, L., Signolet, I., Colas-Ribas, C., Picquet, J., \& Abraham, P. (2018). Ankle brachial index is equally predictive of exercise-induced limb ischemia in diabetic and non-diabetic patients with walking limitation. Journal of Diabetes and its Complications, 32(7), 702-707. https://doi.org/10.1016/j.jdiacomp.2018.03.011

Herdman, H., \& Kamitsuru, S. (2018). NANDA International nursing diagnoses: definitions \& classification 2018-2020 (11th ed.). New York: Thieme, a.s.

Hulme, K., Safari, R., Thomas, S., Mercer, T., White, C., Van der Linden, M., \& Moss-Morris, R. (2018). Fatigue interventions in long term, physical health conditions: a scoping review of systematic reviews. PLoS One, 13(10), e0203367. https://doi.org/10.1371/journal.pone.0203367

Kristianto, H. (2018). The application of NeuroMuscular Tapping (NMT) in The 3rd diabetic foot ulcer In U. B. Rahayu (Ed.), The 2nd Indonesian Neuromuscular Taping Symposium (Vol. 2, pp. 92). Muhammadiyah University Press

Kristianto, H., Hargiani, F. X., \& Dewi, E. S. (2017). Application of neuromuscular taping in patient with 2 year lupus remission with joint pain. In U. B. Rahayu (Ed.), International Symposium On Neuromuscular Taping Concept Methodology, Results and Clinical Experiences (pp. 100105). Muhammadiyah University Press.

Kristianto, H., Waluyo, A., Damayanti, N., Rohyani, R., Kusbandiah, I., Mukaroma, L., Akhsinnadya, F., Indri, M., \& Ahsan. (2019). Erythema and temperature profiles in diabetic foot ulcer with neuromuscular taping intervention. In U. B. Rahayu (Ed.), The 3th Indonesian Neuromuscular Taping Symposium "Neuromuscular Taping Interdisiplinary Approach to Treatment of Neurological Cases, Pain, and Wounds" (pp. 24-28). Muhammadiyah University Press.

Lim, E. C. W., \& Tay, M. G. X. (2015). Kinesio taping in musculoskeletal pain and disability that lasts for more than 4 weeks: is it time to peel off the tape and throw it out with the sweat? A systematic review with meta-analysis focused on pain and also methods of tape application. British Journal of Sports Medicine, 49(24), 1558.

http://dx.doi.org/10.1136/bjsports-2014-094151

Lima, C. R. J., Pires, P. F., Hartz, C. S., de Castro, E. M., Pelai, E. B., \& Bigaton, D. R. (2018). Effects of neuromuscular taping on muscular strength, range of motion and pain intensity in the glenohumeral joint in professional handball athletes: blinded randomized clinical trial. Manual Therapy, Posturology \& Rehabilitation Journal, 15, 480.

Lisowska, B., Siewruk, K., \& Lisowski, A. (2016). Substance P and acute pain in patients undergoing orthopedic surgery. PLoS One, 11(1), e0146400.

https://doi.org/10.1371/journal.pone.0146400

Medina-Mirapeix, F., Bernabeu-Mora, R., M ${ }^{\mathrm{a}}$ Piedad, S.-M., Montilla-Herrador, J., Bernabeu-Mora, M., \& Escolar-Reina, P. (2018). Mobility limitations related to reduced pulmonary function among aging people with chronic obstructive pulmonary disease. PLoS One, 13(5), e0196152. https://doi.org/10.1371/journal.pone.0196152

Pillastrini, P., Rocchi, G., Deserri, D., Foschi, P., Mardegan, M., Naldi, M. T., Villafañe, J. H., \& Bertozzi, L. (2016). Effectiveness of neuromuscular taping on painful hemiplegic shoulder: a randomised clinical trial. Disability and Rehabilitation, 38(16), 1603-1609. https://doi.org/10.3109/09638288.2015.1107631

Renner, C. M. (2012). Kinesio tape and its effects on internal and external range of motion of the shoulder [M.S., Indiana State University]. Health \& Medical Collection; ProQuest Dissertations \& Theses Global. Ann Arbor.

Russo, L., Bartolucci, P., Ardigò, L. P., Padulo, J., Paušić, J., \& Iacono, A. D. (2018). An exploratory study on the acute effects of proprioceptive exercise and/or neuromuscular taping on balance performance. Asian Journal of Sports Medicine, 9(2), e63020. https://doi.org/10.5812/asjsm.63020

Santos, G. L. d.., Souza, M. B.., Desloovere, K., \& Russo, T. L. (2017). Elastic tape improved shoulder joint position sense in chronic hemiparetic subjects: a randomized sham-controlled crossover study. PLoS One, 12(1), e0170368.

https://doi.org/10.1371/journal.pone.0170368

Shah, M., Julu, P. O. O., Monro, J. A., Coutinho, J., Ijeh, C., \& Puri, B. K. (2018). Neuromuscular taping reduces blood pressure in systemic arterial hypertension. Medical Hypotheses, 116, 30-32. https://doi.org/10.1016/j.mehy.2018.04.014

Sinaj, E., Kamberi, F., Ndreu, V., Sinaj, E., \& Nurka(Cina), T. (2015). The effects of taping neuromuscular compare to physical therapies modalities in patients with adhesive capsulitis of the shoulder. European Scientific Journal, ESJ, 11(3), 181-188.

Sterne, J. A., Hernán, M. A., Reeves, B. C., Savović, J., Berkman, N. D., Viswanathan, M., ... \& Carpenter, J. R. (2016). ROBINS-I: a tool for assessing risk of bias in nonrandomised studies of interventions. BMJ, 355, i4919. https://doi.org/10.1136/bmj.i4919

Sundaramurthi, T., Gallagher, N., \& Sterling, B. (2017). Cancer-related acute pain: A systematic review of evidence- 
based interventions for putting evidence into practice. Clinical Journal of Oncology Nursing, 21(3), 13-30.

https://doi.org/10.1188/17.CJON.S3.13-30

Taheri, P., Vahdatpour, B., Asl, M. M., \& Ramezanian, H. (2017). Effects of taping on pain and functional outcome of patients with knee osteoarthritis: a pilot randomized singleblind clinical trial. Advanced Biomedical Research, 6, 139. https://doi.org/10.4103/2277-9175.218031

Thomson, H., Craig, P., Hilton-Boon, M., Campbell, M., \& Katikireddi, S. V. (2018). Applying the ROBINS-I tool to natural experiments: an example from public health [journal article]. Systematic Reviews, 7, 15.

https://doi.org/10.1186/s13643-017-0659-4

Tie Parma, Y., Maher, C., Koes, B., \& Moseley, A. (2017). The PEDro scale had acceptably high convergent validity, construct validity, and interrater reliability in evaluating methodological quality of pharmaceutical trials. Journal of Clinical Epidemiology, 86, 176-181. https://doi.org/10.1016/j.jclinepi.2017.03.002

Törnvall, E., Marcusson, J., \& Wressle, E. (2016). Healthrelated quality of life in relation to mobility and fall risk in 85year-old people: a population study in Sweden. Ageing and Society, 36(9), 1982-1997.
https://doi.org/10.1017/S0144686X15000896

Vallelunga, A., Berlingieri, C., Ragusa, M., Purrello, M., Stabile, M. R., Calabrese, M. C., Morales-Medina, J. C., Palmieri, B., \& Iannitti, T. (2017). Physical rehabilitation modulates microRNAs involved in multiple sclerosis: a case report. Clinical Case Eeports, 5(12), 2040-2043.

https://doi.org/10.1002/ccr3.1100

Villota-Chicaíza, X. M., \& Fernández-Niño, J. A. (2018). Effects of neuromuscular taping as an independent or complementary method to physiotherapeutic treatment in the management of cervical pain. Revista de la Universidad Industrial de Santander. Salud, 50(3), 195-204. http://dx.doi.org/10.18273/revsal.v50n3-2018001

Ward, R. E., Beauchamp, M. K., Latham, N. K., Leveille, S. G., Percac-Lima, S., Kurlinski, L., Ni, P., Goldstein, R., Jette, A. M., \& Bean, J. F. (2016). A novel approach to identifying trajectories of mobility change in older adults. PLoS One, 11(12), e0169003.

https://doi.org/10.1371/journal.pone.0169003

Yeom, H.-A., Baldwin, C. M., Lee, M.-A., \& Kim, S.-J. (2015). Factors affecting mobility in community-dwelling older Koreans with chronic illnesses. Asian nursing research, 9(1), 7-13. https://doi.org/10.1016/j.anr.2014.09.005 